\title{
Synthesis of brushite/polyethylene glycol cement for filler in bone tissue injuries
}

\author{
O.C.Morúa ${ }^{1 *}$, M.J.B. Cardoso ${ }^{2}$, H. N. da Silva ${ }^{1}$, R. G. Carrodeguas ${ }^{1}$, M.A.Rodríguez ${ }^{3}$, M. V. L. Fook \\ ${ }^{I}$ Federal University of Campina Grande, CERTBIO, 58429-900, Campina Grande, PB, Brazil \\ ${ }^{2}$ Federal University of Paraíba, 58052-310, João Pessoa, PB, Brazil \\ ${ }^{3}$ Instituto de Cerámica y Vidrio, CSIC, 28049, Madrid, Spain
}

\begin{abstract}
The objective of this work was to produce brushite cement for orthopedic applications, based on the system wollastonite/phosphoric acid with the incorporation of polyethylene glycol (PEG) as a setting and processing additive. Brushite/PEG cement was obtained by the dissolution-precipitation method and its physicochemical properties were characterized by X-ray diffraction, compressive strength, porosimetry, and biological behavior (cell adhesion and bioactivity tests). The results indicated the formation of brushite cement with 21.4 MPa of compressive strength and 30\% porosity, similar to human trabecular bone. The surface was shown to be adequate for cell adhesion and growth and bioactive with the formation of apatite layers. The incorporation of PEG improved working conditions without causing undesirable changes in the physicochemical properties and biological behavior of developed cement, thus promising for the repair of bone tissue injuries.
\end{abstract}

Keywords: brushite, wollastonite, PEG, bone cements, biomaterials.

\section{INTRODUCTION}

The use of bone graft materials is frequent in the repair of orthopedic defects [1,2]. It exists as natural and synthetic options. Natural substitutes involve autografts, allografts, and xenografts. However, the use of this class of grafts involves limitations regarding the availability and risks of disease transmission [3]. Given these problems, synthetic alternatives have been developed from various materials such as metals [4], polymers [5], ceramics [610], and cements [11-13]. Among calcium phosphate cements, brushite cement receives attention because it is in the form of in situ moldable pastes [9, 14, 15]. Brushite $\left(\mathrm{CaHPO}_{4} \cdot 2 \mathrm{H}_{2} \mathrm{O}\right)$ cement is generally described as biocompatible, bioactive, osteoconductive, bioabsorbable, which are chemically similar to the bone mineral phase and are more readily absorbed than apatite cements [14, 16-18]. Obtaining it involves mixing one or more powders with a liquid [19]. Reported systems include mixtures of calcium orthophosphate and aqueous solutions such as phosphatebuffered saline (PBS) [20], orthophosphoric acid [21, 22], and citric acid [23].

The main disadvantages of brushite-based cements are the handling time which is usually too short to be used efficiently [24] and the temperatures reached by the exothermic cure reaction $[25,26]$. Thus, these cements need additives to adjust their properties for specific applications [22, 26]. Rödel et al. [27] studied PEG hydrogels in cement samples showing that there was no inhibition of brushite

*cumberbatch.otto@gmail.com

Dhttps://orcid.org/0000-0001-5981-8913 phase formation. Evaluations of calcium phosphate cements and their additives have been reported in recent years [28]. Tamimi et al. [29] evaluated the effect of autoclave on the physical and biological properties of calcium phosphate brushite cements on in vitro/in vivo properties; the treatment resulted in a material with improved bone regeneration properties. Laniesse et al. [30] evaluated the manipulation and curing time of wollastonite $\left(\mathrm{CaSiO}_{3}\right)$ based brushite cements. Mosselmans et al. [31] and Egorov et al. [22] evaluated the cure and structure of brushite cement obtained from the phosphoric acid-wollastonite system. In addition, the use of polyethylene glycol (PEG) as an additive in bone cements has been reported [32-34]. However, no studies have been reported on the effects of PEG additives on brushite cement obtained from the wollastonite/phosphoric acid system.

Considering the facts mentioned, the objective of this work was to develop brushite bone cements based on the system wollastonite/phosphoric acid using PEG as a setting modifying and processing additive for orthopedic applications. Their physical-chemical properties were evaluated by $\mathrm{X}$-ray diffraction, compressive strength, and porosimetry tests, and biologically by cell adhesion and bioactivity.

\section{EXPERIMENTAL PROCEDURE}

The reagents used were wollastonite $\left(\mathrm{CaSiO}_{3}\right.$, Vansil W-40, Vanderbilt Min., USA), orthophosphoric acid $\left(\mathrm{H}_{3} \mathrm{PO}_{4}\right.$, Synth, Brazil, 85\%), and polyethylene glycol (PEG, Neon, Germany) with an average molecular weight of 4000 , all of the analytical grade used without further purification. The phosphoric acid added for the conversion 
of $70 \%$ of wollastonite to brushite according to Eq. A was determined stoichiometrically. The amounts used were 2.9 $\mathrm{mL}$ of phosphoric acid solution $(10.22 \mathrm{~mol} / \mathrm{L})$ and $5 \mathrm{~g}$ of wollastonite powder (mesh \#325; <38.1 $\mu \mathrm{m}$ ); they were mixed and homogenized manually for $90 \mathrm{~s}$. PEG 4000 was added in different amounts in relation to the wollastonite mass $(0,0.3,0.45$, and $0.6 \mathrm{wt} \%)$.

$$
\mathrm{H}_{3} \mathrm{PO}_{4}+\mathrm{CaSiO}_{3}+2 \mathrm{H}_{2} \mathrm{O} \rightarrow \mathrm{CaHPO}_{4} \cdot 2 \mathrm{H}_{2} \mathrm{O}+\mathrm{H}_{2} \mathrm{SiO}_{3}
$$

In order to assess the effect of PEG in the setting, the temperature profile of the cement during the setting time was measured in real time with a probe (Testo 177-T4, Pico Technol., UK) using a T-type thermocouple. Exothermic measurements of the profile of the paste during hydration were performed inside an adiabatic chamber specially designed with a T-type thermocouple embedded in the cement paste. All the hydration experiments were performed at $26 \pm 2{ }^{\circ} \mathrm{C}$ and $80 \%$ of humidity. At least two measurements were made for the cement pastes. The resulting paste was poured into Teflon molds for cylindrical specimens with a diameter of $5.8 \pm 0.1 \mathrm{~mm}$ and a height of $12.3 \pm 0.1 \mathrm{~mm}$. Cement was cured at $25 \pm 5{ }^{\circ} \mathrm{C}$ and $80 \% \pm 10 \%$ relative humidity. Brushite/polyethylene glycol (BR/PEG) samples were characterized after a period of $24 \mathrm{~h}$.

The crystalline phases were analyzed by X-ray diffraction (XRD-7000, Shimadzu, Japan), with copper $\mathrm{K} \alpha$ radiation $(1.5418 \AA), 40 \mathrm{kV}$ voltage, $30 \mathrm{~mA}$ current, at $1 \% \mathrm{~min}$ with an integration time of $0.6 \mathrm{~s} / \mathrm{step}$. Quantification of phases, crystallinity, and crystallite sizes was carried out through the Rietveld method with the General System Analyzer Structure (GSAS II) software. For the compressive strength tests, 5 cylindrical specimens were used according to ABNT NBR ISO 5833:2004 standard for 1, 3, and 7 days after curing. A universal testing machine (3366, Instron, USA), with a $10 \mathrm{kN}$ load cell and a constant speed of $1 \mathrm{~mm} / \mathrm{min}$, was used. A mercury intrusion porosimeter (Autopore IV, Micromeritics, USA) was used to quantify the total open porosity and pore size distribution of the developed specimens. For the in vitro cell adhesion assay, samples were first sterilized with ultraviolet light for $30 \mathrm{~min}$ (SCT Power lamp, T8, $80 \mathrm{~W}$ at $255 \mathrm{~nm}$ ). The cells used in the assay were fibroblast type L929 strain deposited on the surface of the samples with an initial cell density of $1 \times 10^{5}$ cells/well using RPMI 1640 culture medium (Gibco). After 7 days of culture, samples were dried in air for $24 \mathrm{~h}$ at $25^{\circ} \mathrm{C}$ and coated with gold by sputtering (Quick Coater SC-701, Sanyu Electron, Japan). The study of cell adhesion on the sample surface was carried out by scanning electron microscopy (SEM) using atmospheric equipment (TM-1000, Hitachi, Japan) working at $15 \mathrm{kV}$. In vitro bioactivity was carried out to evaluate the ability of apatite to form on the surface of the material from immersion in simulated body fluid (SBF). The test was based on ISO 23317:2014 standard. Samples were incubated for 7, 14,21 , and 28 days at $36.5 \pm 0.5^{\circ} \mathrm{C}$ under orbital shaking (SHKE 6000-7, Thermo Sci., USA). After these periods, the samples were dried at $25^{\circ} \mathrm{C}$ for $24 \mathrm{~h}$ and the surface was coated with gold by sputtering and, then, characterized by SEM.

\section{RESULTS AND DISCUSSION}

In order to select the amount of PEG to use in the cement, four compositions were prepared (Table I). Composition without the addition of PEG (W/BR) reached a very high setting temperature $\left(97^{\circ} \mathrm{C}\right)$ in a very short time (Fig. 1). The short working time prevents its application and the high setting temperature can cause necrosis of the surrounding tissues, which makes the formulation useless for application. Samples with higher contents of PEG (W/ BR/PEG-B, W/BR/PEG-C) did not show any appreciable increase in temperature, but the setting time was too long, with no hardening of the pastes being observed after 120 min of mixing (Fig. 1). In the case of $0.3 \%$ of PEG addition (W/BR/PEG-A), the setting time was approximately $77 \mathrm{~min}$, that is a good working time, and the increase of temperature was relatively low, up to $50{ }^{\circ} \mathrm{C}$ in an adiabatic system that will be lower during a real application. For these reasons, this formulation was selected to continue the studies and characterizations.

X-ray diffraction: the XRD pattern of the W/BR/PEG-A sample with the Rietveld refinement is shown in Fig. 2, where the characteristic peaks corresponding to brushite, wollastonite, and PEG-4000 were identified using Inorganic Crystal Structure Database (ICSD) and Crystallography Open Database (COD). According to the sample synthesis, characteristic diffraction peaks were identified for: brushite crystalline phase (centered monoclinic, space group I 12/ a1, according to JCPDS file 96-900-7305) at angles (20) of $11.8^{\circ}, 21.1^{\circ}, 29.5^{\circ}, 30.1^{\circ}$, and $34.3^{\circ}$; crystalline phase of wollastonite (triclinic, space group P-1 according to JCPDS file 00-027-1064) at angles (20) of $11.7^{\circ}, 23.4^{\circ}, 25.5^{\circ}, 27.0^{\circ}$, $29.0^{\circ}$, and $30.2^{\circ}$; these results corroborated the studies in the literature $[21,30,35]$. In addition, characteristic peaks for polyethylene glycol (PEG-4000, orthorhombic, space group Pccn according to files COD 400-1603 and JCPDS 00$049-2095)$ at angles $(2 \theta)$ of $11.5^{\circ}, 11.6^{\circ}, 21.0^{\circ}, 27.0^{\circ}$, and $29.4^{\circ}$ have been considered for Rietveld analysis. Results

Table I - Setting characteristics of wollastonite/polyethylene glycol cements studied.

\begin{tabular}{ccccc}
\hline Characteristic & W/BR & W/BR/PEG-A & W/BR/PEG-B & W/BR/PEG-C \\
\hline PEG amount (wt\% wollastonite) & 0 & 0.30 & 0.45 & 0.60 \\
Max. temperature $\left({ }^{\circ} \mathrm{C}\right)$ & $97 \pm 1$ & $50 \pm 1$ & $27 \pm 1$ & $27 \pm 1$ \\
Time for max. temperature (min) & 2 & 77 & - & - \\
\hline
\end{tabular}




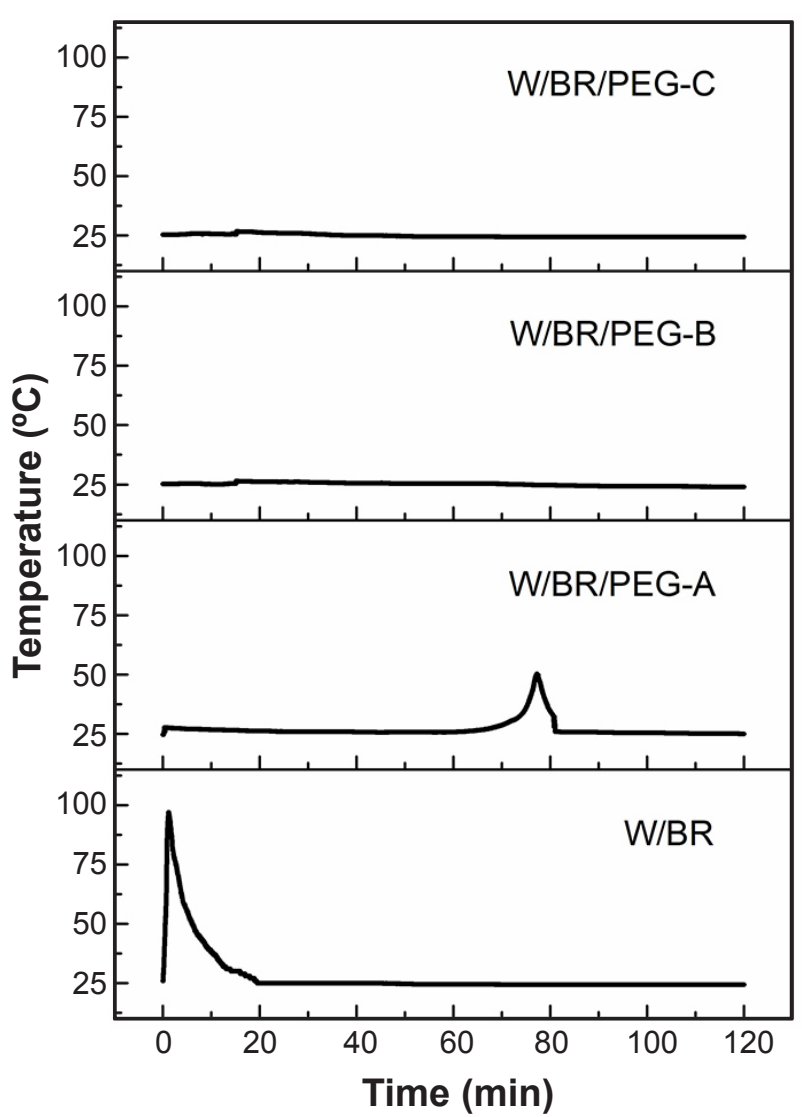

Figure 1: Temperature profile of cement formulations during setting.

of quantification of the phases present in the sample gave $70.9 \%$ and $29.1 \%$ of brushite and wollastonite, respectively. The confidence factor value of the Rwp refinement was $14.5 \%$. It is noteworthy a good confidence factor was achieved, which demonstrated good reliability of the results. It was not possible to quantify the PEG-4000 phase present in the sample as it was in low concentration which may be indicated as doping. Another point that can be observed is

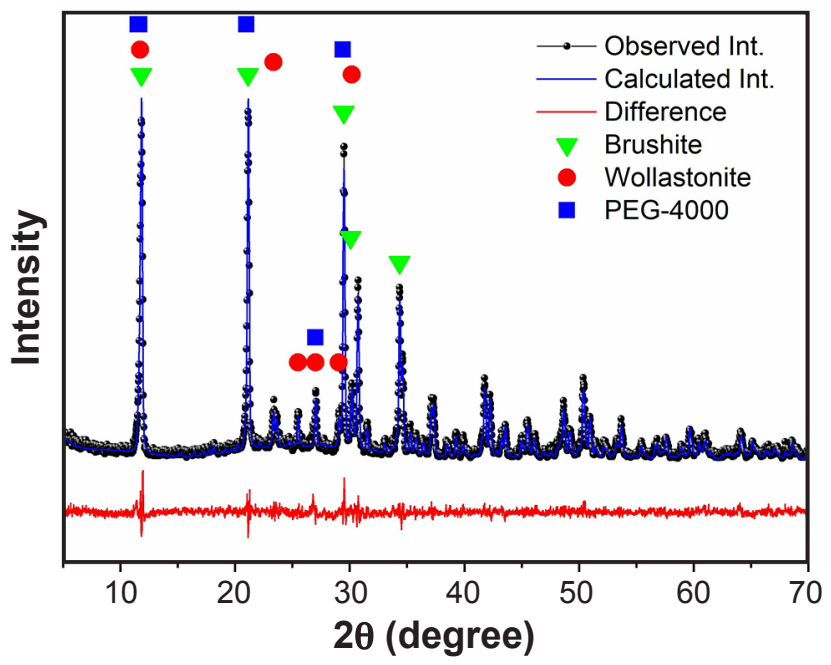

Figure 2: X-ray diffractogram of W/BR/PEG-A cement. that diffraction peaks of this phase presented angles similar to those presented by the brushite and wollastonite phases, so its presence may have only caused changes in the width of the diffraction peaks and consequently a reduction in crystallinity, as can be observed in the diffraction profile of Fig. 2.

Mercury intrusion porosimetry (MIP): Fig. 3 shows the pore size distribution as a function of the intrusion volume of W/BR/PEG-A cement. According to Fig. 3 and Table II, it can be observed that W/BR/PEG-A composition had a narrow pore size distribution, centered around $1200 \mathrm{~nm}$ [36]. The porosimetry data compiled for the cement sample are presented in Table II, including information on maximum intrusion volume, total pore area, mean pore diameter, density, and porosity. A value of $33 \%$ of open porosity is very good for its application as filler for bone tissue injuries. These values were similar to the pore diameters and porosity of cements reported in the literature [37-39].

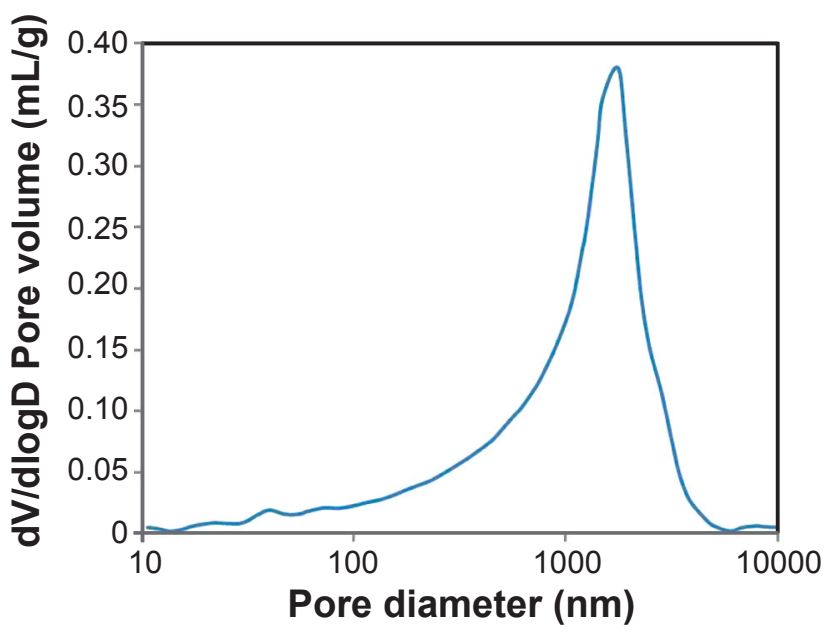

Figure 3: Graph of incremental intrusion volume of mercury vs. pore size diameter of W/BR/PEG-A cement.

Table II - Results of mercury intrusion porosimetry of W/ BR/PEG-A cement.

\begin{tabular}{cc}
\hline Intrusion result & W/BR/PEG-A \\
\hline Maximum intrusion volume $(\mathrm{mL} / \mathrm{g})$ & 0.2 \\
Total pore area $\left(\mathrm{m}^{2} / \mathrm{g}\right)$ & 10.5 \\
Average pore diameter $(\mathrm{nm})$ & 1270 \\
Apparent density $(\mathrm{g} / \mathrm{mL})$ & 2.2 \\
Porosity $(\%)$ & 33 \\
\hline
\end{tabular}

Scanning electron microscopy: in Fig. 4, the morphology of cement after 7 days of cure is shown. An interlocking acicular morphology, several microns in size, and the presence of a second phase, smaller in size, between these needles were observed.

Mechanical test (compressive strength): Fig. 5 shows the evolution of average compressive strength of the W/ BR/PEG-A composition specimens analyzed at different curing times. In the three evaluated times, no significant 


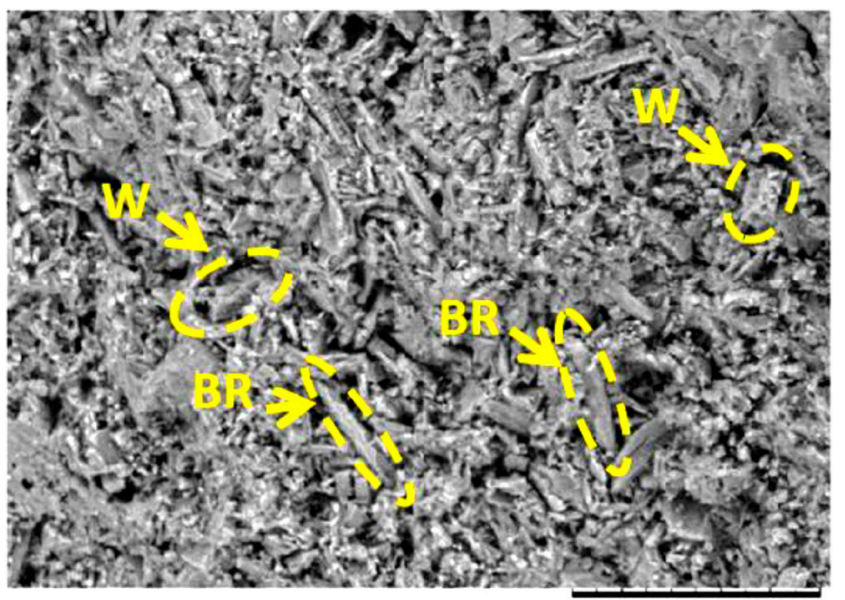

$50 \mu \mathrm{m}$

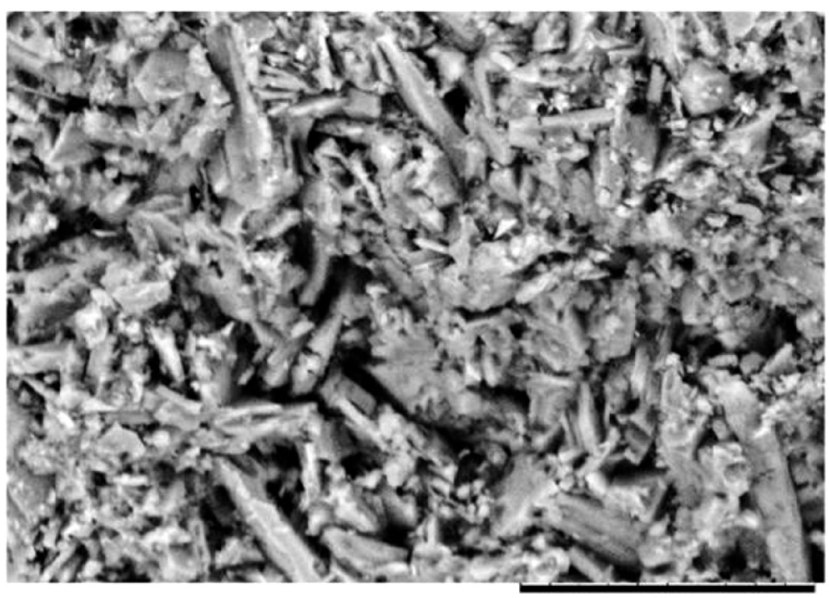

$30 \mu \mathrm{m}$

Figure 4: SEM micrographs of W/BR/PEG-A cement after 7 days of cure.

differences were observed for the W/BR/PEG-A composition, with values of around $21 \pm 2 \mathrm{MPa}$, which matched the porosity obtained $(33 \%)$ in the previous test. It seems that there was a tendency for classic behavior in cements, a high initial value of compressive strength followed by a subsequent decrease and a longterm increase. For the family of calcium orthophosphate cements with applications in orthopedics, there is not yet a specific value of how much they should resist when subjected to compressive stress. Ceramic cements to be applied in medicine are compared with human (trabecular) cancellous bone (10-30 MPa) in some studies [37, 40]. According to Pina and Ferreira [41], brushite cements have a compressive strength of approximately $25 \mathrm{MPa}$. Besides that, Kucko et al. [36] obtained similar results of compressive strength in brushite cements of $23 \mathrm{MPa}$ and a porosity of $30 \%$, which corroborate the results obtained by the mercury porosimetry and compressive strength in the three days of analysis.

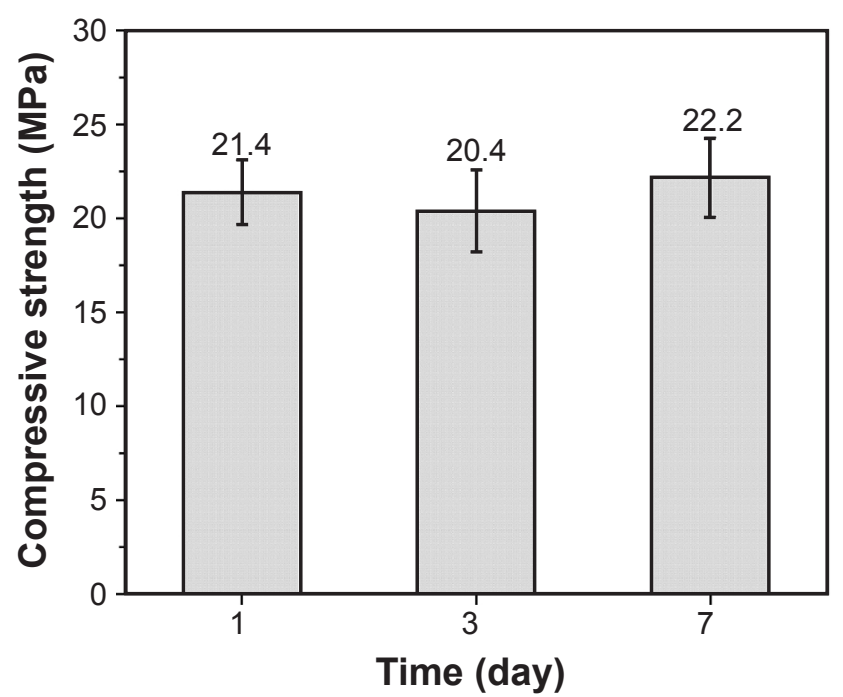

Figure 5: Compressive strength results of W/BR/PEG-A cement at different curing times.
In vitro bioactivity: the formation of the hydroxyapatite layer on the biomaterial surface is an essential requirement for subsequent bone tissue regeneration. Fig. 6 shows the microstructures obtained by SEM with different magnifications of W/BR/PEG-A cement surfaces after 7, 14, 21 , and 28 days of SBF immersion $\left(36.5 \pm 0.5^{\circ} \mathrm{C}\right)$. According to Fig. 4, the sample before being immersed in SBF had an


Figure 6: SEM micrographs showing surfaces of W/BR/PEG-A cement after SBF immersion during: a) 7 days; b) 14 days; c) 21 days; and d) 28 days. 

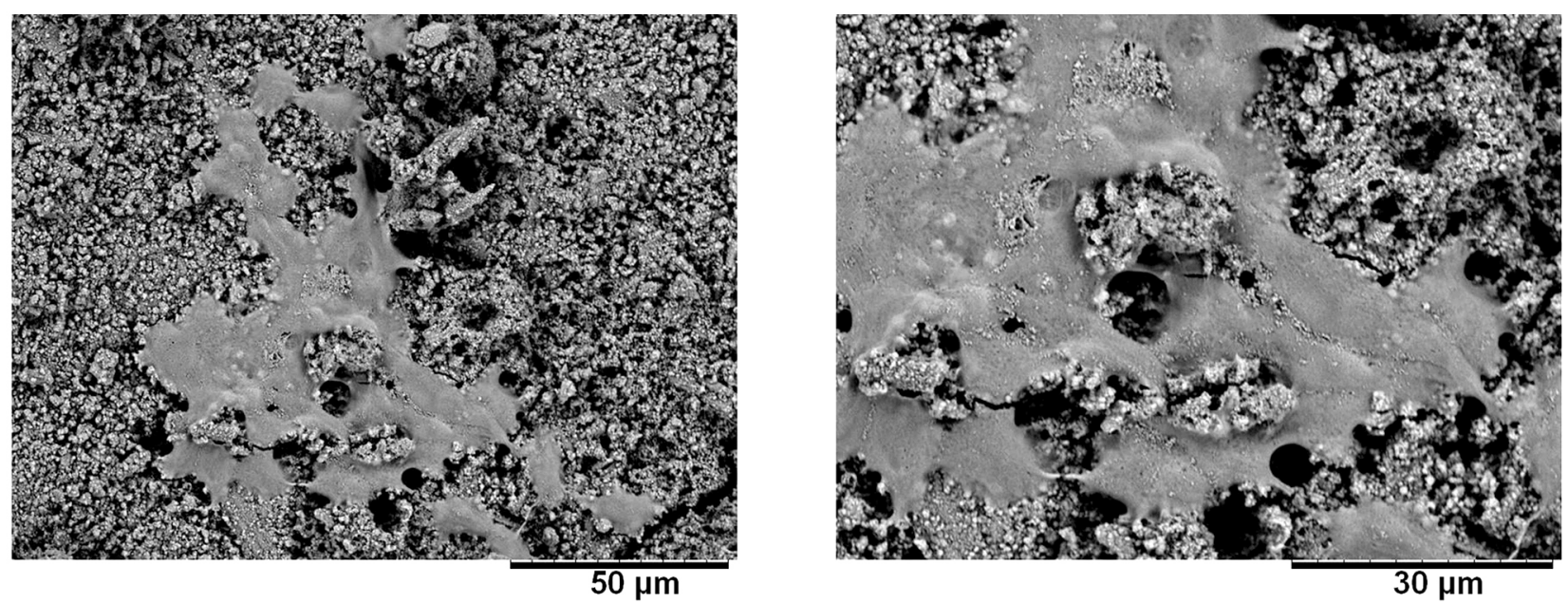

Figure 7: SEM micrographs of W/BR/PEG-A cement surface after 7 days on L929 cells, at different magnifications.

acicular and rough surface morphology. After 7 days of immersion (Fig. 6a1), it was possible to observe a change in the analyzed rough surface, with the growth of a thin layer. Analyzing Fig. 6b2 (high magnification), a morphology in the form of spherical granules probably indicated the formation of carbonate apatite, as observed by Kokubo and Takadama [42], or the first nucleation of hydroxyapatite (HA). At high magnification (Fig. 6a2), a typical morphology known as HA desert flower was observed. It was also observed that the HA layer became thicker with time, as shown in Figs. 6b and 6c [34]. After 28 days of SBF immersion (Fig. 6d), the layer of apatite deposited on the surface of the material was evident, due to its surface roughness, crystalline phase, and porosity $[38,43]$.

In vitro cell adhesion and proliferation: Fig. 7 shows the morphology analyzed by SEM of different regions of bone cement after 7 days of incubation in $\mathrm{L} 929$ cells at $36.5 \pm 0.5{ }^{\circ} \mathrm{C}$. By analyzing the SEM images of the W/BR/PEG-A cement, it was observed that the cell morphology revealed a spreading or proliferation during the 7 days of testing, which we think the cells were in direct contact, adhered to the cement surface, and in a favorable environment for cell proliferation and viability [44]. Rough surface topography is characteristic of porous materials as confirmed by previous porosimetry analysis. The extensions of cells partially covered the sample surface. Also, it was observed that they were in contact with other adjacent cells, forming a cell mat. Therefore, it showed good adhesion, viability, and cell development. Both the surface roughness of the biomaterial and the presences of $\mathrm{Ca}$ and $\mathrm{Si}$ ions act on the favorable cell response and the binding of cells to bioactive cements [45-47]. Although bone cells (osteoblasts) are the most suitable, L929 fibroblast cells are found predominantly in lost or damaged connective tissues, and are important in the tissue repair mechanisms and in the tissue remodeling phase; therefore, it is expected that the biological behavior can be similar when using bone cells (osteoblasts).

The handling of bone cement pastes is an important process for application in filling bone defects; so, evaluations of the rheological behavior of pastes are commonly used to evaluate the injectability of biomaterial. The rheological properties of the developed bone cement were not measured yet; however, the characteristics observed during the time of preparation of the bone cement indicated to be a consistent and malleable paste, similar to descriptions presented in the literature.

\section{CONCLUSIONS}

A brushite-based cement from wollastonite/phosphoric acid was successfully obtained to fill bone defects. Obtaining the brushite phase was confirmed by X-ray diffraction. The use of PEG (0.3 wt \%) allowed to control the setting temperature and time as the workability of the pastes. The compressive strength was compatible with the human trabecular bone tissue. There was evidence that the developed cement may have the properties of being bioactive and capacity for cell proliferation observed in in vitro tests. Thus, it can be concluded that the cement developed has promising physicochemical and biological properties for use in the correction of bone tissue injuries.

\section{ACKNOWLEDGEMENT}

This work was funded by the Social Demand Program of the Coordination for the Improvement of Higher Education Personnel - CAPES, Brazil, with case number: 88882.455354/2019-0.

\section{REFERENCES}

[1] P.V. Giannoudis, H. Dinopoulos, E. Tsiridis, Injury 36, Suppl. 3 (2005) S20.

[2] F. Jin, Y. Xie, N. Wang, X. Qu, J. Lu, Y. Hao, K. Dai, Connect. Tissue Res. 54 (2013) 283.

[3] V. Campana, G. Milano, E. Pagano, M. Barba, C. Cicione, G. Salonna, W. Lattanzi, G. Logroscino, J. Mater. 
Sci. Mater. Med. 25 (2014) 2445.

[4] Q. Chen, G.A. Thouas, Mater. Sci. Eng. R Rep. 87 (2015) 1.

[5] B.D. Boyan, M.I. Baker, C.S.D. Lee, A.L. Raines, A.S. Greenwald, R. Olivares-Navarrete, Z. Schwartz, in "Comprehensive biomaterials", P. Ducheyne (Ed.), Elsevier (2011) 237.

[6] F. Baino, in "Advances in ceramic biomaterials: materials, devices and challenges", P. Palmero, E. Barra, F. Cambier (Eds.), Woodhead (2017) 249.

[7] S. Samavedi, A.R. Whittington, A.S. Goldstein, Acta Biomater. 9 (2013) 8037.

[8] C. Drouet, A. Leriche, S. Hampshire, M. Kashani, A. Stamboulis, M. Iafisco, A. Tampieri, in "Advances in ceramic biomaterials: materials, devices and challenges", $\mathrm{P}$. Palmero, E. Barra, F. Cambier (Eds.), Woodhead (2017) 21. [9] S. Padilla, A.G. de Castro, A. Garzón-Gutiérrez, L. Benito, S. Enciso, M. Canillas, R.G. Carrodeguas, J. Nanomed. Nanotechnol. 6 (2015) 1.

[10] E. de Sousa, M. Motisuke, C.A. Bertran, Cerâmica 58, 348 (2012) 500.

[11] K.L. Low, S.H. Tan, S.H.S. Zein, J.A. Roether, V. Mouriño, A.R. Boccaccini, J. Biomed. Mater. Res. B 94 (2010) 273.

[12] W. Habraken, P. Habibovic, M. Epple, M. Bohner, Mater. Today 19 (2016) 69.

[13] O. Morúa, M. Cardoso, K. Farias, M. Barbero, R. Carrodeguas, M. Fook, Rev. Eletr. Mater. Proc. 12 (2017) 58.

[14] G. Cama, F. Barberis, M. Capurro, L. Di Silvio, S. Deb, Mater. Chem. Phys. 130 (2011) 1139.

[15] H.T. Zhou, N. Zhou, W.H. Huang, J.Y. Wang, Mater. Res. Innov. 19, S10 (2015) 81.

[16] S.V. Dorozhkin, M. Epple, Angew. Chem. Int. Ed. 41 (2002) 3130 .

[17] U. Tariq, R. Hussain, K. Tufail, Z. Haider, R. Tariq, J. Ali, Mater. Sci. Eng. C 103 (2019) 109863.

[18] S. Ghaffari, M. Solati-Hashjin, E. Zabihi-Neyshabouri, S.M. Rabiee, Biomed. Mater. 15 (2020) 35008.

[19] S.V. Dorozhkin, Materials 2 (2009) 221.

[20] M. Montazerolghaem, M. Karlsson Ott, H. Engqvist, H. Melhus, A.J. Rasmusson, Mater. Sci. Eng. C 52 (2015) 212. [21] H.A. Colorado, Z. Wang, J.M. Yang, Cem. Concr. Compos. 62 (2015) 13.

[22] A.A. Egorov, A.Y. Fedotov, I.S. Pereloma, A.Y. Teterina, N.S. Sergeeva, I.K. Sviridova, V.A. Kirsanova, S.A. Akhmedova, A.V. Nesterova, I.V. Reshetov, S.M. Barinov, V.S. Komlev, IOP Conf. Ser. Mater. Sci. Eng. 347 (2018) 12039.

[23] Ö. Demir Oğuz, D. Ege, Materials 11 (2018) 604. [24] M. Bohner, Injury 31 (2000) D37.
[25] C. Liu, W. Gai, S. Pan, Z. Liu, Biomaterials 24 (2003) 2995.

[26] F. Tamimi, Z. Sheikh, J. Barralet, Acta Biomater. 8 (2012) 474.

[27] M. Rödel, J. Teßmar, J. Groll, U. Gbureck, Acta Biomater. 79 (2018) 182.

[28] L.P. Silva, M.D.P. Ribeiro, E.S. Trichês, M. Motisuke, Cerâmica 65, 374 (2019) 261.

[29] F. Tamimi, D.L. Nihouannen, H. Eimar, Z. Sheikh, S. Komarova, J. Barralet, Acta Biomater. 8 (2012) 3161.

[30] P. Laniesse, C.C.D. Coumes, A. Poulesquen, A. Bourchy, A. Mesbah, G. Le Saout, P. Gaveau, Cem. Concr. Res. 106 (2018) 65.

[31] G. Mosselmans, M. Biesemans, R. Willem, J. Wastiels, M. Leermakers, H. Rahier, S. Brughmans, B. Van Mele, J. Therm. Anal. Calorim. 88 (2007) 723.

[32] B. Han, P.-W. Ma, L.-L. Zhang, Y.-J. Yin, K.-D. Yao, F.-J. Zhang, Y.-D. Zhang, X.-L. Li, W. Nie, Acta Biomater. 5 (2009) 3165.

[33] S.Pina, S.I. Vieira, P.M.C. Torres, F. Goetz-Neunhoeffer, J. Neubauer, O.A.B. Cruz e Silva, E.F. Cruz e Silva, J.M.F. Ferreira, J. Biomed. Mater. Res. B 94 (2010) 414.

[34] M. Roy, K. DeVoe, A. Bandyopadhyay, S. Bose, Mater. Sci. Eng. C 32 (2012) 2145.

[35] T. Toshima, R. Hamai, M. Tafu, Y. Takemura, S. Fujita, T. Chohji, S. Tanda, S. Li, G.W. Qin, J. Asian Ceram. Soc. 2 (2014) 52.

[36] N.W. Kucko, R.-P. Herber, S.C.G. Leeuwenburgh, J.A. Jansen, in "Principles of regenerative medicine", $3^{\text {rd }}$ ed., A. Atala, R. Lanza, A.G. Mikos, R. Nerem (Eds.), Acad. Press, Boston (2019) 591 .

[37] S.V. Dorozhkin, Int. J. Mater. Chem. 1 (2011) 1.

[38] S.V. Dorozhkin, J. Mater. Sci. Mater. Med. 24 (2013) 1335.

[39] J. Zhang, W. Liu, V. Schnitzler, F. Tancret, J.-M. Bouler, Acta Biomater. 10 (2014) 1035.

[40] D. Correa, A. Almirall, R. García, L.A. Santos, A.D. Aza, J.A. Delgado, Caract. Estud. Biodegrad. 6 (2011) 100.

[41] S. Pina, J.M.F. Ferreira, Materials 3 (2010) 519.

[42] T. Kokubo, H. Takadama, Biomaterials 27 (2006) 2907.

[43] M.L. Hasan, B. Kim, A.R. Padalhin, O. Faruq, T. Sultana, B.-T. Lee, Mater. Sci. Eng. C 103 (2019) 109775.

[44] D.P. Pioletti, H. Takei, T. Lin, P. Van Landuyt, Q.J. Ma, S.Y. Kwon, K.L.P. Sung, Biomaterials 21 (2000) 1103.

[45] J.L. Aparicio, C. Rueda, Á. Manchón, A. Ewald, U. Gbureck, M.H. Alkhraisat, L.B. Jerez, E.L. Cabarcos, Biomed. Mater. 11 (2016) 45005.

[46] M.L. Hasan, M. Taz, B.-T. Lee, J. Biomed. Mater. Res. B 106 (2018) 2316.

[47] H. Shi, X. Ye, F. He, J. Ye, Colloids Surf. B 177 (2019) 462.

(Rec. 17/07/2020, Rev. 12/01/2021, Ac. 17/02/2021) 